\title{
THE ROLE OF THE POLISH GOVERNMENT IN EXECUTION OF THE JUDGEMENTS OF THE EUROPEAN COURT OF HUMAN RIGHTS
}

\author{
O PAPEL DO GOVERNO POLONÊS NA EXECUÇÃO DE ACÓRDÃOS DO TRIBUNAL EUROPEU DOS \\ DIREITOS HUMANOS
}

Katarzyna Grzelak-Bach ${ }^{1}$

\begin{abstract}
The specificity of the Strasbourg judgments is versatile and concerns many different areas of social life that it is not possible to effectively adapt legal norms and apply their interpretation by one entity of public authority. It can be said with full conviction that the execution of judgments is a continuous process and will last as long as the European Court of Human Rights is functioning; surely it will not end with the completion of the most difficult cases. It is important for the national system for the protection of human rights to be very efficient in the context of the protection of human rights. If, however, there is a violation of the norms of international agreements, Poland must be effective in meeting obligations such as the judgments of the European Court of Human Rights. There are two aspects involved in fulfilling obligations under international law arising from the European Convention for the Protection of Human Rights and Fundamental Freedoms. The first one is the introduction of appropriate standards of respect for the rights and freedoms enshrined in the treaty, and the second one is the obligation to enforce judgments of the European Court of Human Rights in the case of a stated infringement of the Convention. Both obligations must be carried out simultaneously by the state - which, as a party to the Convention, respects its provisions and fulfills the required international legal obligations. The subject of this paper is to present the powers and legitimacy of the body of the executive in Poland in connection with the execution of the judgments of the European Court of Human Rights.
\end{abstract}

Keywords: Human rights. European Court of Human Rights. Execution of judgments. The executive power. Council of Europe.
Resumo: A especificidade dos acórdãos de Strasburg é versátil e diz respeito a muitas áreas diferentes da vida social, e não é possível adaptar eficazmente as normas jurídicas e aplicar suas interpretações por uma única entidade de autoridade pública. Pode-se dizer que a execução das sentenças é um processo contínuo e durará enquanto o Tribunal Europeu dos Direitos do Homem estiver em atividade; seguramente não terminará com a conclusão dos casos mais difíceis. É importante que o sistema nacional de proteção dos direitos humanos seja eficiente no contexto da proteção dos direitos humanos. Se, no entanto, houver violação das normas dos acordos internacionais, a Polônia deve ser eficaz no cumprimento de tais obrigações, como as sentenças da Corte Europeia de Direitos Humanos. Existem dois aspectos envolvidos no cumprimento das obrigações decorrentes do direito internacional da Convenção Europeia para a Proteção dos Direitos Humanos e das Liberdades Fundamentais. A primeira é a introdução de padrões apropriados de respeito aos direitos e liberdades consagrados no tratado, e a segunda é a obrigação de executar sentenças da Corte Europeia de Direitos Humanos no caso de uma violação declarada da Convenção. Ambas as obrigações devem ser cumpridas simultaneamente pelo Estado que, como parte da Convenção, respeita suas disposições e cumpre as obrigações legais internacionais exigidas. O tema deste artigo é apresentar os poderes e a legitimidade do órgão do Poder Executivo na Polônia em conexão com a execução das sentenças da Corte Europeia de Direitos Humanos.

Palavras-chave: Direitos humanos. Tribunal Europeu dos Direitos do Homem. Execução de sentenças. Poder Executivo. Conselho da Europa.

Recebido em 18 de fevereiro de 2019 Avaliado em 14 de junho de 2019 (AVALIADOR A) Avaliado em 13 de junho de 2019 (AVALIADOR B) Aceito em 04 de outubro de 2019

\footnotetext{
${ }_{1} \mathrm{PhD}$ Department of Human Rights Protection and International Humanitarian Law The Cardinal Stefan Wyszyński University in Warsaw, Poland; Faculty of Law and Administration, Cardinal Stefan Wyszyński University in Warsaw; ul. Wóycickiego 1/3 bud. 17, 01-938, Warsaw, Poland; https://orcid.org/0000-0002-8598-0591; katarzynagrzelakbach@gmail.com
} 


\section{Introduction}

The European Convention for the Protection of Human Rights and Fundamental Freedoms (hereinafter referred to as "the Convention") has established the European Court of Human Rights (hereinafter referred to as "the Court" or "ECHR"), which is one of the main bodies charged with the task of the protection of the human rights in Europe. In Poland the Convention, signed at Rome on the 4 Nov. 1950 (European Convention on Human Rights, 1950), is in force since 1993 and since that day it is possible to submit an application to the Court. The Poles started to use that mechanism and the knowledge of a possibility to submit an application to another judicial body has disseminated instantly. With the increase of the number of the member States of the Convention and a rapid increase in the number of the cases heard by the Court the issue of an effective execution of the ECHR judgements has arose. (Barkhuysen, \& Van Emmerik, 2005, p. 3).

Fulfilment by the States of their international obligations arising from the Convention is carried out in two areas. (Krzyżanowska, 2008). The first area covers introduction of proper standards of the protection of human rights and freedoms of the individuals as stated in the aforementioned treaty to a national legal system, whereas the second one covers the obligation of execution of the judgements of the ECHR in the situation where the respondent State was held accountable for the breach of the Convention. (Balcerzak, 2013).

The ECHR judgement declaring the violation of the Convention, is the final act in the court proceedings, which, at the same time, opens another - of not less importance for both parties to the proceedings (the State and the individual) — stage of the execution of the ECHR judgement, namely its implementation by the national authorities. In accordance with art. 46 par. 2 of the Convention execution of the final judgments is supervised by the Committee of Ministers. This most important decision - making body of the Council of Europe consists of the Ministers for Foreign Affairs of all the Member States of this organization. The Republic of Poland is being represented in the Committee of Ministers by the Minister of Foreign Affairs. The task of supervision of the execution of the judgements of the Court the Council of Ministers carries out in a special procedure for human rights cases (so called CM-DH), at four regular meetings ( $\mathrm{DH}$ meetings) every year. On these meetings and also in current works connected with carrying out by Poland its obligations arising from judgements of the Court, the Minister of Foreign Affairs is represented by the Plenipotentiary of the Minister of Foreign Affairs for Proceedings before the European Court of Human Rights or his deputy. (The Ministry of Foreign Affairs Official Journal, 2003). The Convention in its art. 46 states, that the Committee of the Ministers is responsible for the supervision of the execution of judgements of the Court. The activity of the Committee is of a grave importance as a mechanism of protection from ignoring the effects of the judgements. The State has the freedom of choice among the means, that may be introduced in the process of the implementation. It is the State that proposes exact solutions and the Committee of the Ministers conducts the assessment the 
extent of their completeness and appropriateness - with regard to the issue that was the source of violation of the Convention as declared by the Court. This does not change the fact that the actions undertaken in the subject of execution of the ECHR judgement must give guarantee of the efficient execution of the said ECHR judgement.

However, during the years of judicature practice numerous problems have arisen over time with monitoring the activities of the States which voluntarily submit themselves to control of a foreign body and undertake to take actions forced upon them by the body of the Convention.

In Poland there are three groups of executive authorities. The first two are the President of the Republic of Poland and the Council of Ministers (commonly referred to as the Government) and governmental authorities subsidiary to it, among which we have central and local authorities. The Council of Ministers holds all the main competences regarding current policy of the State. The constitutional rule of cooperation of authorities and of social dialogue is not equivalent to inability to resolve a dispute or a debate. The solution of the problem itself is the aim of both the social dialogue and the cooperation of authorities. The word "power" used in the Constitution of the Republic of Poland (1997) (hereinafter referred to as "the RP Constitution") refers to the subject having the possibility to act effectively within the basis of, and within the limits of, the law. The legal solutions referring to the social dialogue and cooperation should create grounds to balance the democracy and efficiency. The mechanism of reaching a decision cannot be created in a way which -in the times of conflict-would benefit one side only or would strip the Council of Ministers from the possibility to carry out the task of ensuring the internal security of the State and public order as imposed on it by the art. 146 of the RP Constitution. (Polish Constitutional Court, 2009).

The President of the Council of Ministers (also called the Prime Minister) on the basis of art. 148 point 4 of the Constitution of the Republic of Poland (1997) "shall [. . .] ensure the implementation of the policies adopted by the Council of Ministers and specify the manner of their implementation". The Prime Minister has a general competence to represent the Council of Ministers and specifies the manner of the implementation of the policies created by the Council of Ministers managed by him. Therefore the actions of the Prime Minister are at the same time arising from the constitutional function of "representing the Council of Ministers" (art. 148 point 1 of the Constitution of the Republic of Poland) and constitutional task of "ensuring the implementation of the policies adopted by the Council of Ministers and specifying the manner of their implementation" (art. 148 point 4 thereof). In the light of the RP Constitution the Council of Ministers is responsible for the execution of the ECHR judgements. (Masternak-Kubiak, 2003).

Executing the foreign policy consists of constitutionally and legally specified actions of the state authorities, connected with control over the relations between the Republic of Poland and international subjects and other participants of the international relations. The RP Constitution of 02 Apr. 1997 divides the competence to execute the foreign policy between the Council of Ministers, the President of the Republic of Poland and the Polish Parliament (which consists of two houses: the 
Sejm and the Senat), but only the Government has the competence of "conducting foreign policy". In accordance with art. $146 \mathrm{sec}$. 1-2 and sec. 4 point 9 of the RP Constitution, the authority which plays the key role in executing the ECHR judgements is the Council of Ministers. (Górecki, 2012).

In the proceedings before the ECHR Poland is represented by the Plenipotentiary of the Minister of Foreign Affairs for Proceedings before the European Court of Human Rights. The Plenipotentiary is being appointed and dismissed by the Minister of Foreign Affairs by the means of a special decision. In executing his tasks, the Plenipotentiary adheres to the need of securing the interests of the Republic of Poland and ensuring that the law, and as such international obligations of the State in the field of human rights, is being respected. The Plenipotentiary in order to fulfil his tasks, must cooperate with representatives of the other public authorities, mainly through meetings of working groups and exchange of correspondence.

Huge diversity and comprehensiveness of the challenges connected with execution of the ECHR judgements have been one of the main reason for searching for the formula, that would allow for regular examination of the compatibility of the national legal provisions and practice with the Strasbourg patterns. (Kwiecien, 2000). First institutional framework regarding execution of ECHR judgements on the national level have been set out in The Government Action Program on the Execution of Judgements of the European Court of Human Rights issued against the Republic of Poland, adopted on 17 May 2007 by the Council of Ministers. Another step towards adopting the most suitable model of cooperation was appointment pursuant to the Ordinance of 19 Jul. 2007 of the then President of the Council of Ministers, Jarosław Kaczyński, of the Interministerial Group on European Court of Human Rights as his opinion-making and advisory body. During its activity the Group in a significant way influenced coordination of the activities of the governmental authorities with regard to the violation of the Convention in order to ensure that the ECHR judgements are executed in a comprehensive manner and in line with Convention standards.

The Interministerial Group on European Court of Human Rights at the time of its appointment in 2007 was a pioneer initiative aiming at coordination of the actions of the Government of the Republic of Poland undertaken with regard to the execution of the ECHR judgements. Is was one of the first structures of such kind among the Council of Europe member States and it has become an inspiration and a role model to follow for the solutions adopted by other States. Since its formation the Group is an efficient mechanism of interministerial cooperation with regard to the issues connected with the issues on execution of the Court judgements by Poland.

Main task of the Group is to monitor the execution of the judgements and the decisions of the Court regarding Poland. Furthermore, experts within the Group, appointed by the ministers with a portfolio, the Chief of the Chancellery of the Prime Minister, the President of the General Counsel to the Republic of Poland, the Plenipotentiary of the Government for the Civic Society and Equal Treatment and-optionally - invited as advisors representatives of other state institutions and offices, of judical and administrative courts, legal professions or non-governmental organizations, are 
working to create suggested solutions aiming at preventing Poland from violating the Convention, asses the compliance of the proposed key legal acts with the Convention and the ECHR judgements and prepare annual information on the state of execution of the ECHR judgements by Poland, which is subsequently adopted by the Council of Ministers. (Council of Europe, 2019).

The Plenipotentiary of the Minister of Foreign Affairs for Proceedings before the European Court of Human Rights is the chairman of the Group. (Biuletyn Informacji Publicznej, 2015). Meetings of the Group are held on a regular basis, at least once in three months, and to deal with the cases, that need not to be heard by all the members of the Group, the chairman of the Group may appoint working and advisory groups. After every meeting of the Group or working group minutes are made, which are accessible for the public since they are put on the website of the Ministry of Foreign Affairs. Thank to intensive works of the members of the Group in the last few years the number of ECHR judgements declared by the Committee of the Ministers of the Council of Europe as executed by Poland has increased significantly and therefore the number of ECHR still to be executed has decreased. In the year 2017 the Committee of the Ministers has declared 133 judgements as executed (in 2016-170 judgements, in 2015-289 judgements), which resulted in the number of the judgements still being reviewed by the Committee of Ministers to plunge and reach the limit of 124 judgements by the end of year 2017. Over the years this number of the judgements still being reviewed is record low. In 2011 the number of the judgements still being reviewed by the Committee of Ministers has exceeded 900 judgements. It should be deemed as the success of the Group that Poland in among the leaders in the number of closed Strasbourg cases (as it is stated in the 11th Annual Report of the Committee of Ministers on the supervision of the execution of judgments from the European Court of Human Rights in 2017, which was published on 04 Apr. 2018). (Hudoc Exec, 2018).

\section{The main problems of the Polish state system indicated by the case law of the European Court of Human Rights. Length of the proceedings}

The unreasonable length of judicial and administrative court proceedings that affected the Polish legal system was also reflected in Strasbourg's case-law. To remedy the situation, the Polish legal system was expanded to include a new measure-a complaint on account of unreasonable length of proceedings. The motivating factor behind the introduction of this solution was the violation found by the ECHR in the judgement in the case of Kudła v. Polan (2000). The remedy was adopted under the Law of 17 Jun. 2004 concerning complaints with regard to a party's rights to case examination in pre-trial proceedings handled or supervised by a prosecutor and in a judicial trial without unreasonable delay. Owing to the defective practice of domestic courts in employing the said remedy, as found in the Court's judgements, it was duly amended under the aforementioned law. Despite the original imperfection of the adopted measure, the Polish model of examining 
complaints regarding the unreasonable length of proceedings has been replicated in the legal order of numerous Member States of the Council of Europe. (Gonera, 2012). Legal amendments concerning the unreasonable length of judicial and administrative court proceedings proved indispensable as well. Amended legislation included articles 149 and 154 of the Law on Proceedings before Administrative Courts. The intended purpose of legislative changes was to improve the efficiency of and simplify and speed up proceedings before administrative courts, i.a. by conferring upon the judiciary the competence to rule on failure to act or unreasonable length of proceedings, even if the said proceedings have already concluded. (Górski, 2017, pp. 233-293).

Access to the court, quality of legal assistance provided by a solicitor in the case of the so-called lawyer's counsel.

Defined as the Quality of Legal Assistance Provided by an Ex Officio Representative in Cases of Compulsory Barrister's Acting. The Civil Proceedings Code was amended in conjunction with the Court judgements adverse to Poland, namely in the cases of Siałkowska v. Poland (2007) and Staroszczyk v. Poland (2007). These cases concerned violations of the applicants' rights of access to the Supreme Court due to their not having received information of the ex officio plenipotentiary's refusal to file a cassation appeal in civil proceedings in timely or proper manner. A similar effect was achieved in criminal cases without the need for legislative amendments. The Supreme Court's uniform ruling practice clearly outlined the scope of the responsibilities of the courts of second instance, which-should an ex officio legal representative submit an opinion on the existence of a lack of grounds to file cassation - are obliged to duly notify the parties concerned of the possibility of the establishment of such extraordinary appeal remedy by a legal representative of choice, whereas the term for filing shall re-commence as of the day of such notification being delivered. Amendments have been further applied to the Law on Proceedings before Administrative Courts on account of the ECHR judgement in the case of Subicka v. Poland (2010). The case involved a refusal by a barrister appointed under a pro bono legal assistance scheme to file a cassation complaint with the Supreme Administrative Court. The amendment instituted multiple procedural guarantees concerning pro bono legal assistance and the manner for defining the cassation complaint filing term, allowing a complainant to file a cassation complaint via a legal representative of their choice, the opinion of an ex officio representative on the existence or a lack of grounds to establish cassation notwithstanding.

\subsection{The rights of incapacitated persons}

The case of Kędzior v. Poland (2010) concerned the placement of incapacitated persons in nursing homes and the lack of such persons' direct access to court for the purposes of applying for the restoration of their legal capacity. For the purposes of executing the aforementioned judgement 
and a similar judgement in the case of K.C. v. Poland (2014), a law amending the Mental Health Protection Law and other selected laws was adopted.

\subsection{The right to own and respect property}

The Court's pilot judgement in the case of Broniowski v. Poland (2005), regarding the property abandoned in territories beyond the River Bug, included a statement that the violation of the applicant's rights guaranteed under Article 1 of Protocol No. 1 to the Convention arises from a universal issue caused by the incorrect operation of Polish legislation and administrative practice. A River Bug territory compensation scheme was set up to execute the said judgement by adopting a law concerning the exercise of rights to compensation for abandoning property beyond the current borders of the Republic of Poland. In the case of Hutten-Czapska v. Poland (2006), the Court found a violation of Article 1 of Protocol No. 1 to the Convention on account of the regulated property rent scheme prevalent in the past in Poland, as the applicant could not use her property at will or collect the rent in the amount of her choosing. Circumstances changed after the adoption of the 2006 act concerning amendments to the Act on the Protection of Tenants' Rights, municipal residential assets, and on the amendment of the Civil Code.

\subsection{Rights of Persons Detained in Penitentiary Institutions}

Polish penitentiary law was subject to a number of amendments for the purpose of executing multiple Court judgements concerning a variety of imprisonment-related aspects. Primarily, in conjunction with judgements in the cases of Orchowski v. Poland (2009) and Sikorski v. Poland (2009), wherein the Court recognized overpopulation in Polish prisons as a structural issue, provisions of Polish criminal and penitentiary law affecting overpopulation in penitentiary institutions were amended. Furthermore, a number of organizational steps were taken with the intention of eliminating the overpopulation phenomenon in penitentiary institutions. By virtue of the decisions of 12 Oct. 2010 in the cases of Łatak v. Poland (2010) and Łomiński v. Poland (2010), the ECHR confirmed the effectiveness of personal property protection lawsuits as a remedy allowing for the pursuit of compensation on account of having been placed in an overpopulated penitentiary institution. The Executive Criminal Code was also amended, i.a. for the purpose of executing judgements in the cases of Horych v. Poland (2012) and Piechowicz v. Poland (2012), concerning the regime of executing imprisonment sentences with regard to persons classified as requiring detainment in a designated block or cell of a remand prison or closed-regime penitentiary institution in conditions warranting increased societal protection and security of the remand prison or penitentiary institution, i.e. as "dangerous detainees". Amendments to Polish law introduced as a result of the said judgements allowed for the elimination of formerly applied automatism in 
classifying detainees as "dangerous" and provided options for the gradual mitigation of the rigors involved when classifying detainees under the said category. Furthermore, regulations were adopted with the aim of eliminating the censorship of correspondence between detainees and human rights protection bodies, in case of Klamecki v. Poland (2003) (No. 2), improving the effectiveness of measures aimed at preventing suicide attempts by detainees (Jasińska v. Poland, 2010) and guaranteeing the immediate execution of court rulings resulting in the restoration of freedom (Mamełka v. Poland, 2012).

\section{Conclusion}

Although Poland is at the forefront of the Council of Europe Member States in terms of the number of pending complaints, it has been explained, among others, by the fact that our countrymen appreciate the opportunity to complain to an international body. (Glas, 2016). In addition, the number of cases has been decreasing for several years and simultaneously the number of cases lost by Poland is decreasing. (Christoffersen, \& Madsen, 2011).

The most common thematic areas of complaints are: the excessive length of court and other institutions proceedings (mainly the latter), dubious reasons for decisions, problems with parents' rights to contact and care for children, as well as the violation of the right to freedom and personal security (also in the context of lengthy conduct of proceedings e.g. cases related to pre-trial detention). As practice shows, the independence of the realization by the Council of Ministers of legal and international obligations resulting from membership in the Council of Europe would not be effective without cooperation with other state authorities, including judicial authorities. The abovementioned statistical data clearly indicate that Poland is constantly improving the way, in which it is fulfilling its obligation to enforce ECHR judgments. Certainly, the appointment of specialized structures, i.e. the Plenipotentiary of the Minister of Foreign Affairs for proceedings before the European Court of Human Rights and the Group on the European Court of Human Rights, as well as the development of the Government Action Program on the Execution of Judgements of the European Court of Human Rights issued against the Republic of Poland, had a great impact in this area. Extensive interministerial cooperation and cooperation with other entities allows for the effective execution of judgments in the Polish law and practice system of national authorities, which since 2007 clearly brings about a dynamic implementation of the ECHR judgments. (Bodnar, 2018).

\section{References}

Balcerzak, M. (2013). The liability of the member State of the European Convention for the Protection of Human Rights and Fundamental Freedoms. Poland: TNOiK Publishing. 
Barkhuysen, T., \& Van Emmerik, M. (2005). A comparative view on the execution of the judgments of the European Court of Human Rights. In T. A. Christou, \& J. P. Raymond (Eds.), European Court of Human Rights, remedies and execution of judgments. UK: British Institute of International and Comparative Law.

Biuletyn Informacji Publicznej. (2015). Organy pomocnicze Prezesa Rady Ministrów. Zespół do spraw Europejskiego Trybunału Praw Człowieka. Retrieved from: https://bip.kprm.gov.pl/kpr/ bip-rady-ministrow/organy-pomocnicze/organy-pomocnicze-preze/159,Zespol-do-spraw-Europejskiego-Trybunalu-Praw-Czlowieka.html

Bodnar, A. (2018). Execution of judgements of the European Court of Human Rights in Poland. Institutional dimension. Poland: Wolters Kluwer Poland.

Broniowski v. Poland, app. No. 31443/96 (ECHR, Sept. 28, 2005). Retrieved from http://hudoc. echr.coe.int/eng? $\mathrm{i}=001-70326$

Christoffersen, J., \& Madsen, M. R. (Eds.). (2011). The European Court of Human Rights beetwen Law and Politics. UK: Oxford.

Constitution of the Republic of Poland of 1997, Pub. No. 78, item 483, Journal of Laws of the Republic of Poland (1997). Retrieved from https://www.sejm.gov.pl/prawo/konst/angielski/ kon1.htm

Council of Europe. (2019). CM/Rec(2008)2 on efficient domestic capacity for rapid execution of judgments. Retrieved from https://www.coe.int/en/web/human-rights-intergovernmental-cooperation/echr-system/recommendation-on-execution-judgments.

European Convention on Human Rights. (1950). Convention for the Protection of Human Rights and Fundamental Freedoms. Retrieved from https://www.echr.coe.int/Documents/Convention ENG.pdf

Glas, L. R. (2016). The Theory, Potential and Practice of Procedural Dialogue in the Europe-an Convention on Human Rights System. Cambridge, UK: Antwerp-Portland.

Gonera, K. (2012). Effective remedies from the perspective of common national courts. Proceedings of the Warsaw Seminar on Human Rights, Warsaw, Poland, 5.

Górecki, D. (Ed.). (2012). Polish constitutional law. Poland: Wolters Kluwer Poland. 
Górski, M. (2017). The Dialogue between Selected CEE and the ECH. In A. Wyrozumska, Transnational Judicial Dialogue on International Law in Central and Eastern Europe. Poland: Łód $\square$ Univesity Press.

Horych v. Poland, app. No. 13621/08 (ECHR, Apr. 17, 2012). Retrieved from http://hudoc.echr. coe.int/eng? $\mathrm{i}=001-110440$

Hudoc Exec. (2018). Retrieved from https://hudoc.exec.coe.int

Hutten-Czapska v. Poland, app. No. 35014/97 (ECHR, June 19, 2006). Retrieved from http:// hudoc.echr.coe.int/eng? $\mathrm{i}=001-75882$

Jasińska v. Poland, app. No. 28326/05 (ECHR, June 01, 2010). Retrieved from http://hudoc.echr. coe.int/eng? $\mathrm{i}=001-99000$

K.C. v. Poland, app. No. 31199/12 (ECHR, Nov. 25, 2014). Retrieved from http://hudoc.echr.coe. int/eng? $\mathrm{i}=001-148259$

Kędzior v. Poland, app. No. 45026/07 (ECHR, Oct. 16, 2010). Retrieved from http://hudoc.echr. coe.int/eng? $\mathrm{i}=001-100409$

Klamecki v. Poland (No. 2), app. No. $31583 / 96$ (ECHR, Apr. 03, 2003). http://hudoc.echr.coe.int/ eng? $\mathrm{i}=001-60996$

Krzyżanowska, M. M. (2008). The Reception of the EHCR. In H. Keller, \& S. A. Stone (Eds.), The Impact of the ECHR on National Legal Systems. UK: Oxford University Press.

Kudła v. Poland, app. No. 30210/96 (ECHR, Oct. 26, 2000). Retrieved from http://hudoc.echr.coe. int/eng? $\mathrm{i}=001-58920$

Kwiecień, R. (2000). Place of the international treaties in legal order of the Polish State. Poland: Wydawnictwo Sejmowe Warsaw.

Łatak v. Poland, app. No. 52070/08 (ECHR, Oct. 12, 2010). Retrieved from http://hudoc.echr.coe. int/eng? $\mathrm{i}=001-101349$

Łomiński v. Poland, app. No. 33502/09 (ECHR, Oct. 12, 2010). http://hudoc.echr.coe.int/ eng ? $\mathrm{i}=001-101350$ 
Mamełka v. Poland, app. No. 16761/07 (ECHR, Apr. 17, 2012). Retrieved from http://hudoc.echr. coe.int/eng? $\mathrm{i}=001-110465$

Masternak-Kubiak, M. (2003). Respecting the international law in the light of the Constitution of the Republic of Poland. Poland: Wolters Kluwer Poland.

Orchowski v. Poland, app. No. 17885/04 (ECHR, Oct. 22, 2009). Retrieved from http://hudoc.echr. coe.int/eng? $\mathrm{i}=001-95314$

Piechowicz v. Poland, app. No. 20071/07 (ECHR, Apr. 17, 2012). Retrieved from http://hudoc.echr. coe.int/eng? $\mathrm{i}=001-110499$

Polish Constitutional Court, No. 37/06 (Apr. 08, 2009). Retrieved from https://ipo.trybunal.gov. $\mathrm{pl} / \mathrm{ipo} /$ Sprawa? cid $=1 \&$ dokument $=258 \&$ sprawa $=4182$

Siałkowska v. Poland, app. No. 8932/05 (ECHR, Mar. 22, 2007). Retrieved from http://hudoc.echr. coe.int/eng? $\mathrm{i}=001-79887$

Sikorski v. Poland, app. No. 17599/05 (ECHR, Oct. 22, 2009). Retrieved from http://hudoc.echr. coe.int/eng? $\mathrm{i}=001-95317$

Staroszczyk v. Poland, app. No. 59519/00 (ECHR, Mar. 22, 2007). Retrieved from http://hudoc. echr.coe.int/eng? $\mathrm{i}=001-79879$

Subicka v. Poland, app. No. 29342/06 (ECHR, Oct. 14, 2010). Retrieved from http://hudoc.echr. coe.int/eng? $\mathrm{i}=001-100409$

The Ministry of Foreign Affairs Official Journal. (2003). No. 4, item 53 with subsequent amendments. 
